\title{
New localities of rare species of the genus Microbotryum
}

\author{
ANDRZEJ CHLEBICKI \\ Department of Mycology, W. Szafer Institute of Botany, Polish Academy of Sciences \\ Lubicz 46, PL-31-512 Kraków, a.chlebicki@botany.pl
}

Chlebicki A.: New localities of rare species of the genus Microbotryum. Acta Mycol. 45 (2): 169-173, 2010.

Microbotryum bistortum, $M$. dianthorum, M. superbum and M. langerheimii, rare species of smut fungi are reported from new localities in Poland, mostly in protected areas. Dianthus superbus subsp. superbus is a new host for M. superbum observed. Taxonomical status of $M$. carthusianorum and M. superbum is discussed in the paper.

Key words: Pucciniomycotina, occurrence, ecology, protected areas

\section{INTRODUCTION}

Twenty eight species of the genus Microbotryum Lév. belonging to Microbotryales (Pucciniomycotina) have been recorded in Poland so far (Piątek et al. 2005; Majewski et al. 2008; Lutz et al. 2008). These fungi are specialized plant pathogens attacking anthers, rarely ovaries, semens and leaves. Recent changes in the fungal systematics concern also the genus Microbotryum. Last investigations show that the species of the genus Microbotryum invading plant anthers of Caryophyllaceae form a monophyletic group (Almaraz et al. 2002, Begerow et al. 2004; Lutz et al. 2005). In spite of this statement some authors include species invading plants from other families in the genus Microbotryum (Vánky 1998, 2004; Lutz et al 2005). Fungi from the genus Microbotryum which infect plants from the family Caryophyllaceae form sori, mostly in plant anthers, whereas M. major (J. Schröt.) G. Deml \& Oberw. form sori also in plant ovaries, anthers and basal part of petals. These fungi are not always host specialized, some of them are restricted to single plant genus, others can infect different plant genera. Moreover, the same host plant can be invaded by various anther smuts (see Dianthus carthusianorum in this article). Revisions of material collected in Poland as well as corrections of nomenclature are necessary to keep up with changes in the fungal taxonomy. 
Distribution of these fungi in Poland as well as their host range are poorly known. Few localities of the species were reported from some national parks and reserves. New information on four rare species is presented in the paper.

\section{METHODS}

Collected material was examined under light microscope Nikon Eclipse 91. The spores were mounted in lactophenol and gently heated to boiling point (Vánky 1994). For each specimen at least 30 spores were measured.

\section{RESULTS}

Microbotryum bistortarum (DC.) Vánky

Fig. 1A

Mycotaxon 67: 40, 1998. Basionym: Uredo bistortarum DC., in de Candolle \& Lamarck, Fl. franç., Edn 3 (Paris) 5/6: 76, 1815. Caeoma bistortarum (DC.) Link, Willd. Sp. Plant. 6(2): 10, 1825. Ustilago bistortarum (DC.) Körn., Hedwigia 16: 38, 1877. Bauhinus bistortarum (DC.) Denchev, Mycotaxon 65: 421, 1997.

Locality. Kraków, Nowa Huta, protected ecological area „Łąki Nowohuckie”, in flowers of Polygonum bistorta L., 21 May 2009, coll. A. Chlebicki, KRAM F-47391 (Fig. 1A). CommENTs. So far the fungus has been reported only from areas of Karkonosze Mts near Karpacz (Schroeter 1887), Mt. Śnieżnik, Babia Góra Massif and Tatra Mts (Kochman, Majewski 1973). The fungus was noted mainly in flowers of Polygonum bistorta, but in the Tatra Mts it was also observed in bulbils of P. viviparum L. (Kochman, Majewski 1973). Only four attacked plants were noted in the new locality „Ląki Nowohuckie" in spite of the fact that the host plant occurs very commonly here.

Microbotryum dianthorum (Liro) H. Scholz et I. Scholz

Englera 8: 206, 1988. s. lato. Basionym: Ustilago dianthorum Liro, Ann. Acad. Sci. Fenn., Ser. A 17(1): 35, 1924.

Locality. Warmia Region, „Rzeka Drwęca” Reserve, Pusta Dąbrówka, in the meadow near Drwęca River, in anthers of Dianthus carthusianorum L., 19 July 2008, coll. A. Chlebicki, KRAM F-46785. Sudetes, Góry Złote Mts, meadow near Mąkolno and Laski, in anthers of Dianthus carthusianorum, 12 October 2007, coll. A. Chlebicki, KRAM F-56614.

CommenTs. Only few specimens of the host plant were noted in the meadows, all of them were invaded by the fungus. According to Gac et al. (2007) and Refrégier et al. (2008) Microbotryum dianthorum is probably a collective species, which occurs on various species of the genus Dianthus. Recently, Denchev et al. (2009) separated a new species from M. dianthorum - M. carthusianorum Denchev, Giraud \& M. E. Hood, which occurs on D. carthusianorum. However, on the same host plant another fungus species - Microbotryum shykoffianum Giraud, Denchev \& de Hood 


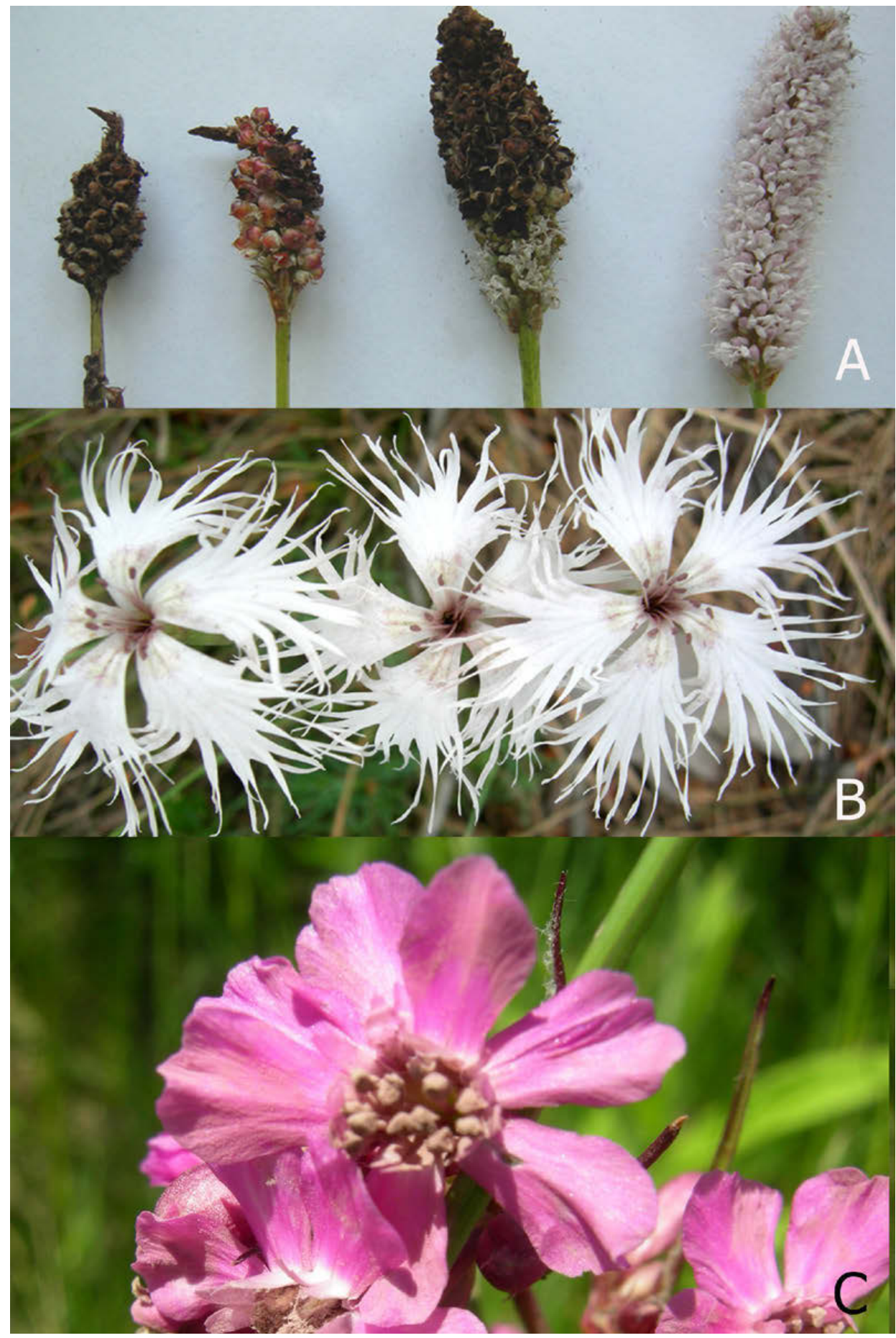

Fig. 1. A - Microbotryum bistortarum in flowers of Polygonum bistorta; B - M. superbum in anthers of Dianthus superbus subsp. superbus; $\mathrm{C}$-Microbotryum lagerheimii in anthers of Lychnis viscaria. 
can occur. Separation of this new species is controversial and not accepted by some mycologists. At this moment the author temporarily included specimens collected on Dianthus carthusianorum in Microbotryum dianthorum s. lato. An acceptance of the new taxonomical decision will be possible after obtaining of precise descriptions of these two Microbotryum species inhabiting Dianthus carthusianorum (M. carthusianorum and M. shykoffianum). These species do not differ morphologically, and their identification is possible only on the basis of molecular examination of DNA sequences of $\beta$-tub, $\gamma$-tub and EF1 $\alpha$.

Microbotryum superbum (Liro) Denchev, T. Giraud \& M. E. Hood

Fig. 1B

Mycol. Balcanica 6: 83, 2009. Basionym: Ustilago superba Liro, Ann. Acad. Sci. Fenn., Ser. A, 17(1): 37, 1924.

LocAlity. Podlasie Region, pine forest near Mikaszewo Lake, the area protected in the frame of NATURA 2000 programme „Puszcza Augustowska”, in anthers of Dianthus superbus L. subsp. superbus, 11 June 2008, coll. A. Chlebicki, KRAM F-46708 (Fig. 1B).

COMmEnts. Nearly half of an abundant population of Dianthus superbus subsp. superbus was invaded by fungus. Specimens inhabiting Dianthus superbus were in the past placed in Microbotryum violaceum (Pers.) G. Deml \& Oberw. (Denchev, Sharkova 1997). Earlier Liro (1924) described a new species of fungus on the same host and named it Ustilago superba Liro. Denchev et al. (2009) followed his decision and proposed a new combination - Microbotryum superbum (Liro) Denchev Giraud \& M. E. Hood. Refrégier et al. (2008) reported this species as MVDsp. 2 in the flowers of D. superbus, D. monspessulanus L. and D. gratianopolitanus Vill.

Microbotryum superbum differs from the $M$. dianthorum in physiological and genetic characters, but morphology is of their spores identical (Le Gac et al. 2007; Denchev et al. 2009). My observations partially confirm the opinion of these authors (Denchev et al. 2009). The host populations of Dianthus superbus subps. superbus and $D$. carthusianorum examined were growing separately and occupied different niches. Microbotryum dianthorum s. lato was noted in Poland on six species of Dianthus (Kochman, Majewski 1973), among them also on D. superbus subsp. speciosus (Rchb.) Hayek from the Babia Góra Massif. Majewski et al. (2008) listed all known localities of $M$. dianthorum from Poland. D. superbus subsp. superbus is a new host plant for M. superbum in this country.

Microbotryum lagerheimii Denchev

Fig. 1C

Mycol. Balcanica 4: 64, 2007.

Locality: Western Carpathians, Beskid Sądecki Mts, Poprad Landscape Park, meadow on Mt. Okraglica Południowa, in the anthers of Lychnis viscaria L., 1 June 2008, coll. A. Chlebicki, KRAM F-46668 (Fig. 1C).

CoMments: Host plants were growing abundantly along roads and in meadows (ca some hundred specimens). Almost all of them were parasitized by the fungus. Previously the fungus was noted on Lychnis viscaria (=Viscaria vulgaris) in some localities in Lower Silesia: Jarnołtów near Wrocław, Pątnów Legnicki, Ratyń near Środa Śląska, Kłodzko, Dzierżoniów, Bystrzyca Górna near Świdnica, Łęknice near Żarów as Ustilago antherarum (DC) Fr. and U. violacea (Pers.) Roussel (Schroeter 1887; Denchev 2007), also in Mazowsze Region and Puszcza Kozienicka and Na- 
tolin near Warszawa, as Ustilago violacea and U. silenes-inflatae Liro (Kochman, Majewski 1973; Denchev 2007).

Denchev (2007) separated Microbotryum lagerheimii from M. silenes-inflatae (Liro) G. Deml \& Oberw. on the basis of colour of ustilospore mass, characters of ustilospores and range of the host plants. So far in Poland, specimens parazitizing Lychnis viscaria have been included in the species M. silenes-inflatae (Majewski et al. 2008). Denchev (2007) examined anther smuts collected on this host in Poland and transferred them to $M$. lagerheimii. Sori of the specimens collected by the author have pale vinaceous to hazel coloured powdery mass of ustilospores (Fig. 1C), typical of M. lagerheimii.

Acknowledgements. The author thanks Dr. Marcin Piątek and anonymous reviewer for valuable comments, as well as Dr. Cvetomir Denchev for sending his new articles and short discussion of taxonomy of $M$. dianthorum. The study was supported by the Ministry of Science and Higher Education, Poland (Project No. N N304 328336).

\section{REFERENCES}

Almaraz T., Roux C., Maumont S., Durrieu G. 2002. Phylogenetic relationships among smut fungi parasitizing dicotyledons based on ITS sequence analysis. Mycol. Res. 106 (5): 541-548.

Begerow D., Göker M., Lutz M., Stoll M. 2004. On the evolution of smut fungi on their hosts. (In): A. Agerer, M. Piepenbring, D. Blanz (eds). Frontiers in Basidiomycete Mycology. IHW-Verlag, Eching: 81-98.

Denchev C., Sharkova S. 1997. Taxonomic revision of Microbotryum (Ustilaginales) on Dianthus. Phytologia Balcanica 3 (1): 105-112.

Denchev C. 2007. Microbotryum lagerheimii sp. nov. (Microbotryaceae). Mycol. Balcanica 4: 61-67.

Denchev C., Giraud T., Hood M. E. 2009. Three new species of anthericolous smut fungi on Caryophyllaceae. Mycol. Balcanica 6: 79-84.

Kochman J., Majewski T. 1973. Podstawczaki (Basidiomycetes). Głowniowe (Ustilaginales). (In:) J. Kochman, A. Skirgiełło (eds). Flora Polska. Rośliny zarodnikowe Polski i ziem ościennych. Grzyby (Mycota), 5. PWN, Warszawa-Kraków, 270 pp.

Le Gac M., Hood M. E., Giraud T. 2007. Phylogenetic evidence of host-specific cryptic species in the anther smut fungus. Evolution 61: 15-26.

Liro J. I. 1924. Die Ustilagineen Finlands. I. Annales Academiae Scientiarum Fennicae, Ser A 17(1): I-XVIII + 1-636.

Lutz M., Göker M., Piątek M., Kemler M., Begerow D., Oberwinkler F. 2005. Anther smuts of Caryophyllaceae: molecular characters indicate host-dependent species delimitation. Mycol. Progress. 4: 225-238.

Lutz M., Piątek M., Kemler M., Chlebicki A., Oberwinkler F. 2008. Anther smuts of Caryophyllaceae: molecular analyses reveal further new species. Mycol. Res. 112(11): 1280-1296.

Majewski T., Piątek M., Ruszkiewicz-Michalska M. 2008. Ustilaginales. (In:) W. Mułenko, T. Majewski, M. Ruszkiewicz Michalska (eds). A preliminary checklist of micromycetes in Poland. (In:) Z. Mirek (ed.). Biodiversity of Poland 9: 297-318.

Piątek M., Ruszkiewicz-Michalska M., Mułenko W. 2005. Catalogue of Polish smut fungi, with notes on four species of Anthracoidea. Polish Bot. J. 50 (1): 19-37.

Refrégier G., Le Gac M., Jabbour F., Widmer A., Yockteng R., Shykoff J. A., Hood M. E., Giraud T. 2008. Cophylogeny of the anther smut fungi and their caryophyllaceous hosts: Prevalence of host shifts and importance of delimiting parasite species for inferring cospeciation. BMC Evolutionary Biology 8: 100.

Schroeter J. 1887. Die Pilze Schlesiens: Ustilaginei. (In:) F. Cohn (ed.). Cryptogamen-Flora von Schlesien 3(1): 261-290. J. U. Kern's Verlag, Breslau.

Vánky K. 1994. European smut Fungi. G. Fischer Verlag, Stuttgart-New York, 570 pp.

Vánky K. 1998. The genus Microbotryum (smut fungi). Mycotaxon 67: 33-60.

Vánky K. 2004. Anther smuts of Caryophyllaceae. Taxonomy, nomenclature, problem in species delimitation. Mycol. Balcanica 1: 189-191. 
Nowe stanowiska rzadkich gatunków grzybów z rodzaju Microbotryum

\section{Streszczenie}

Grzyby z rodzaju Microbotryum Lév. są obecnie zaliczane do podgromady Pucciniomycotina, gdzie wchodzą w skład rzędu Microbotryales R. Bauer \& Oberw. W Polsce dotychczas odnotowano 28 gatunków z tego rodzaju. Są to wyspecjalizowane patogeny roślin atakujące głównie pylniki, rzadziej słupki, nasiona i liście. Zachodzące w ostatnich latach zmiany w taksonomii wymagają dostosowania nazewnictwa i przejrzenia dotychczas zebranych materiałów. Rozmieszczenie tych grzybów w Polsce jest słabo poznane. Nieliczne stanowiska wielu gatunków tych grzybów były podawane z niektórych parków narodowych i rezerwatów przyrody. Również zakres żywicieli jest w Polsce niedostatecznie poznany. W niniejszej notatce zostały przedstawione informacje o czterech gatunkach tych grzybów: Microbotryum bistortarum, M. dianthorum, M. superbum i M. lagerheimii. 